great increase in papers in this subject, and will enable the editorial staff, which now includes American as well as British members, to accept additional American contributions without reducing the publica. tion facilities which were available to the original members of the Association. It should also result in a greatly increased circulation. It is obvious from a perusal of the first volume of the new journal (which fortunately has not commenced re-numbering its volumes but is issued as Vol. 6, Nos. 1 and 2 . Pp. $126+4$ plates. Published twice yearly. Annual subscription 50s.; United States and Canada 8 dollars. London: Baillière, Tindall and Cox, Ltd., 1958) that it is the intention of the editors to maintain the existing high standard. The new venture should be warmly welcomed and given every encouragement.

\section{Courses in Higher Technology}

THE London and Home Counties Regional Advisory Council for Higher Technological Education has produced a bulletin (Bulletin of Special Courses in Higher Technology, including Management Studies and Commerce, 1958-9, Part 1 : Autumn Term. Pp. 122. (London: London and Home Counties Regional Advisory Council for Higher Technological Education, 1958.) 3s.) giving details of special advanced courses held in the London and Home Counties region which do not regularly appear in college calendars or prospectuses as part of a grouped course or as subjects offered for endorsement on Higher National Certificates. They are, as a rule, part-time (usually evening) courses, but full-time courses which are specially arranged and are not of longer than three months duration are also included. Sessional evening postgraduate courses leading to higher degrees in science (including mathematics) and engineering are not included in the Bulletin. Among the courses are macromolecular chemistry and structural design in aluminium at Battersea College of Technology; physical methods of assessing flour quality and pulse techniques at the Borough Polytechnic; applied ultrasonics at Brunel College of Technology; taxation case law at the City of London College; technical Russian at the Ewell County Technical College ; and bacteriology for public health engineers at the Imperial College of Science and Technology.

\section{The Night Sky in October}

New moon occurs on Oct. 12d. 20h. 52m. U.T., and full moon on Oct. 27d. 15h. 41m. The following conjunctions with the Moon take place; Oct. 2 d. 18h., Mars $2^{\circ}$ N. ; Oct. 17d. 0lh., Saturn $3^{\circ}$ S. ; Oct. 29d. 19h., Mars $3^{\circ} \mathrm{N}$. There will be a total eclipse of the Sun on October 12, invisible at Greenwich. Mercury is too close to the Sun for observation. Venus is a morning star, but is now unfavourably placed for observation. Mars rises at $19 \mathrm{~h} .40 \mathrm{~m}$. $18 \mathrm{~h} .45 \mathrm{~m}$. and $17 \mathrm{~h} .25 \mathrm{~m}$. at the beginning, middle and end of the month, respectively ; it is visible throughout the night. Its stellar magnitude increases during the month from $-1 \cdot 1$ to $-1 \cdot 8$, its distance from the Earth decreasing from 56 to 46 million miles. Mars moves eastwards until October 9 , when it reaches a stationary point. It is then between the Pleiades and the Hyades. After October 9, Mars begins to retrograde but it remains in Taurus throughout the month. Jupiter is too close to the Sun for observation. Saturn sets at $20 \mathrm{~h} .35 \mathrm{~m} ., 19 \mathrm{~h} .45 \mathrm{~m}$. and $18 \mathrm{~h} .50 \mathrm{~m}$. at the beginning, middle and end of the month, respectively; the planet may be visible for a short time low in the south-west after sunset, but conditions for observation are not favourable. Occultations of stars brighter than magnitude 6 are as follows, observations being made at Greenwich: Oct. 3d. $03 \mathrm{~h} .16 \cdot 6 \mathrm{~m} ., \delta$ Tau. $(D)$; Oct. 3d. 03h. $59 \cdot 6 \mathrm{~m}$. , $\delta$ Tau. $(R)$; Oct. 3d. 05h. 00.8m., 64 Tau. $(R)$; Oet. 8 d. $03 \mathrm{~h} .15 \cdot 1 \mathrm{~m} ., A^{2}$ Cnc. $(R) . \quad D$ and $R$ refer to disappearance and reappearance, respectively. The Orionid meteors are active during the third week of the month, conditions being moderately favourable; the radiant is near R.A. 6 h. 24 m., Dec. $+15^{\circ}$.

\section{Announcements}

Dr. HenRY S. ODBERT has been appointed programme director for psychobiology, Division of Biological and Medical Sciences, U.S. National Science Foundation. Dr. Odbert was formerly chief of the Occupational Analysis Branch of the Personnel Laboratory of the Wright Air Development Center, Lackland Air Force Base, Texas.

Dr. B. Cinader has resigned from the post of principal scientific officer in the Department of Experimental Pathology at the Agricultural Research Council Institute of Animal Physiology at Babraham, Cambridge, and has been appointed head of the Subdivision of Immunochemistry in the Ontario Cancer Institute and associate professor in the Department of Medical Biophysics of the University of Toronto (500 Sherbourne Street, Toronto 5).

THE International Trust for Zoological Nomenclature announces that it has accepted with regret the resignation of Mr. Francis Hemming as a member of the Trust and as managing director and secretary. Lt.-Col. F. J. Griffin, who is an original member of the Trust, has been appointed managing director and secretary. Mr. R. V. Melville, who has been acting assistant manager, has been appointed scientific controller, with responsibility for the scientific and editorial work hitherto carried out by Mr. Hemming.

A symposium on "Batteries" will be held at the Signals Research and Development Establishment, Christchurch, Hants, during October 21-23. Further information can be obtained from the Organizer, Battery Symposium, at the above address.

THE second Technical Convention of the Indian Institution of Telecommunication Engineers will be held in New Delhi on December 27 and 28, when papers will be read on the following subjects: antenna and wave propagation, broadcasting in India, tropicalization of communication equipment, semiconductors, telephone communication in India, navigational aids, atmospheric and radio noise. Papers intended for presentation at the Convention should preferably deal with original investigations or describe developmental work embodying novel features. The last date for the receipt of abstracts of proposed papers is October 15. Further details may be obtained from the Honorary Secretary, Institution of Telecommunication Engineers, Post Box No. 481, New Delhi.

Erratum. In the communication entitled "Dissociation of Serological Complexes of Ovalbumin and Hæmoglobin using Aqueous Carbon Dioxide", by Dr. B. T. Tozer, K. A. Cammack and Dr. H. Smith, published in Nature of September 6, p. 669, column 2, line 6 should read "confirmed by measurements of light absorption at $410 \mathrm{~m} \mu$ ", and not "confirmed by measurements of light at $410 \mathrm{~m} \mu$ " as printed. 